\title{
Pengembangan Lembar Kegiatan Siswa (LKS) Berbasis Potensi Lokal pada Mata Pelajaran Biologi SMA Kelas XII
}

\author{
Natalia Kristiani Lase ${ }^{1}$ Herbert Sipahutar ${ }^{2}$ Fauziyah Harahap $^{3}$ \\ ${ }^{1}$ Dosen IKIP Gunungsitoli, Nias- Sumatera Utara, Indonesia \\ ${ }^{2}$ Program Studi Pendidikan Biologi Pascasarjana, Universitas Negeri Medan, Sumatera Utara, Indonesia \\ E-mail:natalialase@yahoo.com
}

\begin{abstract}
This research was aimed to develop a Student Activity Sheet (SAS) based on local potency for biology grade XII which is feasible empirically. Eligibility Worksheet was obtained through validation of subject matter experts to assess the feasibility of the content and presentation of the feasibility of worksheets, design expert to assess the feasibility of the design worksheets to SAS developed. Exploiting local potency in accordance with a curriculum that gives freedom to each school consider the potency of the school and the surrounding area. This can be done by incorporating elements of local potency in learning activities through the creation of learning media in the form of worksheets. Examples of local potencies have been integrated into the SAS are distilled palm wine processing (integrated into cell metabolism, fermentation alcohol), the activity of the material have been incorporated in a biotechnology are activities of coconut extraction to produce edible oil. This research and development using 4-D model of development research which comprises the step of define, design, develop and disseminate, however the disseminate stage of this study was not done. The procedure starts from the development stages: (1) problem analyze; (2) design of SAS; (3) validation and field trials SAS. The instruments used were sheets covering the aspects of feasibility validation of content, presentation feasibility, feasibility of the design and questionnaire responses of teachers and students. Data validation and the questionnaire responses of teachers and students were analyzed descriptively qualitative. Feasibility content and feasibility contents presentation SAS based on local potency at biology grade XII has been developed by subject matter experts is very good, in which the feasibility of the content had an average percentage score of $88.10 \%$ and feasibility aspects of the presentation of SAS has an average percentage score of $91.35 \%$. Feasibility design SAS based on local potency at biology grade XII has been developed according to the expert design is very good with a percentage score of $97.00 \%$.
\end{abstract}

Key Words: worksheet development, biology, high school, local content or wisdom

\section{PENDAHULUAN}

Biologi adalah salah satu mata pelajaran sains yang menekankan pada kinerja ilmiah dan pemahaman konsep serta penerapannya dalam kehidupan sehari-hari. Konsep-konsep dalam biologi saling berkaitan. Pemahaman salah satu konsep berpengaruh terhadap konsep yang lain.

Salah satu penyebab rendahnya prestasi belajar siswa khususnya pada mata pelajaran biologi adalah adanya miskonsepsi. Miskonsepsi muncul karena setiap konsep biologi harus dikuasai dengan benar sebelum mempelajari konsep lainnya. Dalam proses menyatukan informasi baru ke dalam struktur kognitif mereka, siswa seringkali mengalami kesulitan, bahkan kegagalan. Siswa cenderung menghapal konsep dibanding menerapkan konsep.
Miskonsepsi memberikan banyak dampak negatif di dalam pembelajaran. Apabila miskonsepsi siswa terhadap suatu konsep biologi berkembang lebih lanjut, maka menyebabkan gangguan pada proses pengolahan konsep dalam struktur kognitif yang dilakukan oleh siswa; menyebabkan kesulitan dalam menghubungkan konsep yang satu dengan konsep yang lain; miskonsepsi tersebut resisten untuk diubah dan cenderung untuk bertahan pada pikiran siswa dimulai saat siswa memperoleh konsep tersebut bahkan sampai dewasa (Tekkaya, 2002). Soyibo (1995) mengemukakan bahwa miskonsepsi dapat menghambat pemahaman yang bermakna dan kinerja yang baik dalam pelajaran serta merupakan salah satu sumber kesulitan belajar. Banyak konsep dalam biologi 
saling berhubungan erat satu sama lain dan konsep yang satu merupakan kunci untuk memahami konsep-konsep lain.

Miskonsepsi dapat muncul dari proses pembelajaran di sekolah atau lingkungan luar sekolah sebagai hasil interprestasi siswa itu sendiri. Di sekolah, guru berperan dalam proses pembelajaran dan siswa berperan sebagai peserta didik. Dalam proses tersebut, guru menggunakan buku teks dan LKS sebagai salah satu sumber belajar dan menyampaikannya pada siswa.

Berdasarkan hasil observasi awal tentang LKS yang digunakan oleh siswa diketahui bahwa LKS yang digunakan siswa SMA di Kota Gunungsitoli belum sesuai dengan pengertian LKS yang sesungguhnya. LKS yang digunakan belum mendorong siswa untuk belajar bermakna dan menemukan konsep dengan benar. LKS tersebut hanya berisi rangkuman materi biologi umum yang sebenarnya telah banyak dikembangkan dalam buku-buku pelajaran. LKS ini juga berisi kumpulankumpulan soal yang kemudian dijadikan guru sebagai tugas/pekerjaan rumah bagi siswa. Siswa hanya dituntut mengerjakan soal-soal latihan yang ada dalam LKS, tanpa memahami materi terlebih dahulu.

Selain itu, LKS yang ada belum berbasis potensi lokal Nias. Padahal banyak potensi lokal yang dapat diangkat dalam pembelajaran biologi, namun dalam kenyataannya belum dimanfaatkan dalam pembelajaran. Bahasa, gambar, serta contoh-contoh yang digunakan dalam LKS tidak cocok dengan kondisi atau potensi lokal maupun karakteristik siswa yang berada di Pulau Nias, sehingga masih harus dilakukan penyesuaian-penyesuaian karena tidak akrab dengan kehidupan sehari-hari siswa. Hal yang demikian kurang sesuai dengan Permen RI 2005 tentang Sistem Pendidikan Nasional yang menyatakan bahwa kurikulum pada semua jenjang dan jenis pendidikan dikembangkan dengan prinsip diversifikasi sesuai dengan satuan pendidikan, potensi daerah, dan peserta didik, dengan memperhatikan keragaman potensi daerah dan lingkungan.

Pemanfaatan potensi lokal sebagai sumber belajar merupakan salah satu karakteristik yang diharapkan kurikulum agar pembelajaran menjadi aplikatif dan bermakna (Sarah, 2014). Potensi lokal adalah potensi sumber daya spesifik yang dimiliki suatu daerah meliputi sumber daya alam, manusia, teknologi, dan budaya. Melalui potensi lokal yang terintegrasi dalam pembelajaran menjadikan siswa termotivasi untuk mempelajarinya, sehingga pembelajaran menjadi bermakna. Hal ini dapat dilakukan dengan memasukkan unsur potensi lokal dalam kegiatan pembelajaran melalui pembuatan media pembelajaran berupa LKS. Potensi lokal memberikan kesempatan bagi guru untuk memudahkan dalam mengaitkan pengetahuan baru yang akan disampaikan kepada siswa (Sajidan, 2014).

Oleh karena itu, diperlukan suatu solusi alternatif dalam mengatasi masalah tersebut. Salah satunya dengan mengembangkan sebuah LKS berbasis potensi lokal Nias dengan menggunakan pendekatan saintifik. Menurut Hamalik (2008), kegiatan pembelajaran yang dapat membuat siswa lebih aktif dan dapat melakukan kegiatan secara langsung akan membuat kegiatan belajar mengajar menjadi lebih bermakna dan mengurangi terjadinya miskonsepsi. Kegiatan yang ada pada LKS dengan pendekatan ilmiah dapat mendorong dan menginspirasi siswa untuk dapat memahami, menerapkan, dan mengembangkan pola berpikir yang rasional dan objektif dalam merespon substansi atau materi pembelajaran (Kemdikbud, 2013).

Menurut Ahmadi (2012), keunggulan lokal adalah potensi suatu daerah untuk menjadi produk atau jasa yang bernilai dan dapat menambah penghasilan daerah dan bersifat unik serta memiliki keunggulan kompetitif. Asmani (2012) menjelaskan bahwa potensi lokal merupakan segala sesuatu yang menjadi ciri khas kedaerahan yang dimanfaatkan sebagai kepentingan hidup masyarakat, memenuhi aspek ekonomi, budaya, teknologi informasi, komunikasi, ekologi, dan lainnya. Di Amerika pembelajaran berbasis potensi lokal disebut sebagai Place ased Education (PBE) yang diartikan sebagai "pendidikan 
berbasis tempat/lokal". Ausubel mendefinisikan PBE adalah "pendidikan yang menggunakan masyarakat lokal dan lingkungan untuk mengajarkan konsepkonsep seni, bahasa, matematika, ilmu-ilmu sosial, ilmu pengetahuan alam, dan pelajaran lainnya dalam kurikulum".

Potensi lokal dapat dimanfaatkan dalam pembelajaran, baik sebagai media pembelajaran ataupun sumber belajar. Pembelajaran menggunakan potensi lokal akan mengasah pengetahuan, keterampilan, dan sikap siswa. Pada aspek kognitif, siswa diarahkan untuk memikirkan sebuah cara untuk mengembangkan atau memanfaatkan potensi lokal yang ada didaerah mereka. Aspek sikap peserta didik juga akan berkembang seiring dengan pembelajaran yang menggunakan masalah lokal sebagai media pembelajaran yang akan mengembangkan sikap peduli peserta didik terhadap daerah mereka. Aspek keterampilan juga sendirinya akan berkembang, karena kemampuan keterampilan yang baik dibutuhkan dalam proses pengembangan dan pemecahan masalah lokal yang ada.

Penggunaan potensi lokal dalam pembelajaran melatih kemampuan siswa untuk bersosialisasi dan keterampilan memecahkan masalah, sejalan dengan yang dijelaskan oleh Sobel dalam Ahmadi (2012) bahwa pendidikan berbasis lokal akan memberikan kesempatan kepada siswa untuk belajar mengidentifikasi masalah dan memecahkan masalah potensi lokal di daerahnya dan merupakan investasi bagi kesejahteraan masyarakat dan aksi sosial.

Asmani (2012) menjelaskan bahwa ruang lingkup pembelajaran berbasis potensi lokal terdiri dari beberapa hal, yaitu: a) Lingkup situasi dan kondisi daerah, yaitu segala sesuatu yang ada di daerah tersebut yang berkaitan dengan lingkungan alam, sosial, ekonomi, seni dan budaya atau lainnya yang berupa hasil bumi, tradisi, pelayanan/jasa, atau lainnya yang menjadi keunggulan daerah;

Lingkup keunggulan lokal meliputi potensi keunggulan lokal, cara mengelola, cara mengolah/mengemas, mengoptimalkan, memasarkan, atau proses lain yang mampu membuat nilai tambah bagi daerah sehingga dapat meningkatkan taraf hidup maupun pendapatan hasil daerah.

Pulau Nias merupakan pulau kecil yang termasuk ke dalam Propinsi Sumatera Utara. Pulau yang terdiri atas empat kabupaten dan satu kotamadya. Nias memiliki potensi kekayaan alam yang beragam dan diantaranya banyak tidak dimiliki oleh daerah lain. Jenis potensi kekayaan alam tersebut tersebar diseluruh kepulauan Nias dengan karakteristik masing-masing daerah sangat berbeda. Namun tidak semua potensi lokal Nias dapat digunakan dalam pembelajaran, harus disesuaikan dengan materi pembelajarannya.

Pada penelitian ini, peneliti akan mengembangkan sebuah LKS yang mengaitkan potensi lokal kedalam materi pembelajaran dan aktivitas siswa. Potensi lokal yang diangkat adalah pengolahan tuak suling dapat diintegrasikan ke dalam materi fermentasi alkohol; hasil penelitian genetik yang dilakukan terhadap masyarakat Nias; situs-situs purbakala yang dapat dihubungkan dengan materi evolusi; industri rumah tangga pembuatan tahu, roti, minyak goreng dapat diintegrasikan ke dalam materi bioteknologi, potensi sumber daya alam (tumbuhan dan hewan) yang ada di Museum Pusaka Nias dapat diintegrasikan ke dalam materi pertumbuhan dan perkembangan.

Menurut Prastowo (2011) LKS merupakan bahan ajar cetak berupa lembaran-lembaran yang disusun secara sistematis berisi materi, ringkasan dan petunjuk pelaksanaan pembelajaran bertujuan agar dapat menuntun siswa melakukan kegiatan yang aktif mengacu pada kompetensi dasar. Lembar kegiatan ini dapat berupa panduan untuk latihan pengembangan aspek kognitif maupun panduan untuk pengembangan semua aspek pembelajaran dalam bentuk panduan eksperimen. LKS bertujuan untuk menemukan konsep atau prinsip dan aplikasi konsep atau prinsip.

Prastowo (2011) menjelaskan terdapat empat poin penting yang menjadi tujuan penyusunan LKS, yaitu sebagai berikut: a) 
Menyajikan bahan ajar yang memudahkan peserta didik untuk memberi interaksi dengan materi yang diberikan. b) Menyajikan tugas-tugas yang meningkatkan penguasaan peserta didik terhadap materi yang diberikan. c) Melatih kemandirian belajar peserta didik. d) Memudahkan pendidik dalam memberikan tugas kepada peserta didik.

Manfaat penggunaan LKS bagi kegiatan pembelajaran menurut Prastowo (2011) adalah: a) Mengaktifkan siswa dalam proses pembelajaran. b) Membantu siswa dalam mengembangkan konsep. c) Melatih siswa dalam menemukan dan mengembangkan keterampilan proses. d) Melatih siswa untuk memecahkan masalah dan berpikir kritis. e) Sebagai pedoman guru dan siswa dalam melaksanakan proses pembelajaran. f) Membantu siswa memperoleh catatan tentang materi yang dipelajari melalui kegiatan belajar. g) Membantu siswa menambah informasi tentang konsep yang dipelajari melalui kegiatan belajar secara sistematis.
Arsyad
(2012)
beberapa

mengemukakan kelebihan LKS, antara lain: a) Siswa dapat belajar dan maju sesuai dengan kecepatan masing-masing sehingga siswa diharapkan dapat menguasai materi pelajaran tersebut. b) Di samping dapat mengulangi materi dalam media cetakan, siswa akan mengikuti urutan pikiran secara logis. c) Memungkinkan adanya perpaduan antara teks dan gambar yang dapat menambah daya tarik, serta dapat memperlancar pemahaman informasi yang disajikan. d) Khusus pada teks terprogram, siswa akan berpartisipasi dengan aktif karena harus memberi respon terhadap pertanyaan dan latihan. e) Materi dapat direproduksi dengan ekonomis dan didistribusikan dengan mudah.

Syarat-syarat yang harus dimiliki dalam menyusun LKS menurut Darmodjo (dalam Trianto, 2010) sebagai berikut:

1. Syarat-syarat didaktik. LKS sebagai salah satu bentuk sarana berlangsungnya proses pembelajaran haruslah memenuhi persyaratan didaktik, artinya harus mengikuti asasasas pembelajaran yang efektif,
2. Syarat-syarat konstruksi. Syarat konstruksi adalah syarat-syarat yang berkenaan dengan penggunaan bahasa, susunan kalimat, kosa-kata, tingkat kesukaran, dan kejelasan yang pada hakikatnya haruslah tepat guna dalam arti dapat dimengerti oleh pihak penggunan yaitu anak didik.

3. Syarat-syarat teknis yaitu:

a) Tulisan, al-hal yang perlu diperhatikan antara lain menggunakan huruf yang jelas dan mudah dibaca, meliputi jenis dan ukuran huruf. Menggunakan huruf tebal yang agak besar untuk topik. Perbandingan ukuran huruf dan ukuran gambar serasi.

b) Gambar. Gambar yang baik dapat menyampaikan pesan secara efektif pada pengguna LKS untuk mendukung kejelasan konsep.

c) Penampilan. Penampilan dibuat menarik. Kemenarikan penampilan LKS akan menarik perhatian siswa, tidak menimbulkan kesan jenuh dan membosankan. LKS yang menarik adalah LKS yang memiliki kombinasi antara gambar, warna dan tulisan yang sesuai.

\section{METODE}

Penelitian ini merupakan penelitian pengembangan, di mana perangkat yang dikembangkan adalah LKS dengan model pengembangn 4D (define, design, develop, dan disseminate) namun hanya dilakukan sampai tahap pengembangan (develop) saja. Setelah LKS selesai didesain, maka LKS akan divalidasi oleh 3 dosen ahli materi dan 2 dosen ahli desain dengan tujuan untuk mengetahui kelayakan LKS yang dikembangkan secara teoritis. Instrumen yang digunakan adalah lembar validasi yang meliputi aspek kelayakan penyajian, kelayakan isi materi, kelayakan dan kelayakan desain. Metode pengumpulan data dalam penelitian ini adalah dengan metode pengumpulan hasil validasi, kemudian data yang didapatkan dianalisis secara deskriptif kualitatif.

\section{HASIL DAN PEMBAHASAN}


Berdasarkan hasil penilaian oleh validator ahli materi untuk komponen kelayakan isi, diperoleh bahwa sub komponen penilaian terhadap kesesuaian materi dengan KI dan KD memiliki persentase rata-rata $91.67 \%$, kebenaran konsep 86.11\% , keluasan konsep 97.22 \% dan pemahaman konsep $81.67 \%$. Untuk lebih jelasnya, hasil perolehan data grafik secara empiris dapat dilihat pada Gambar 1.1. di bawah ini.

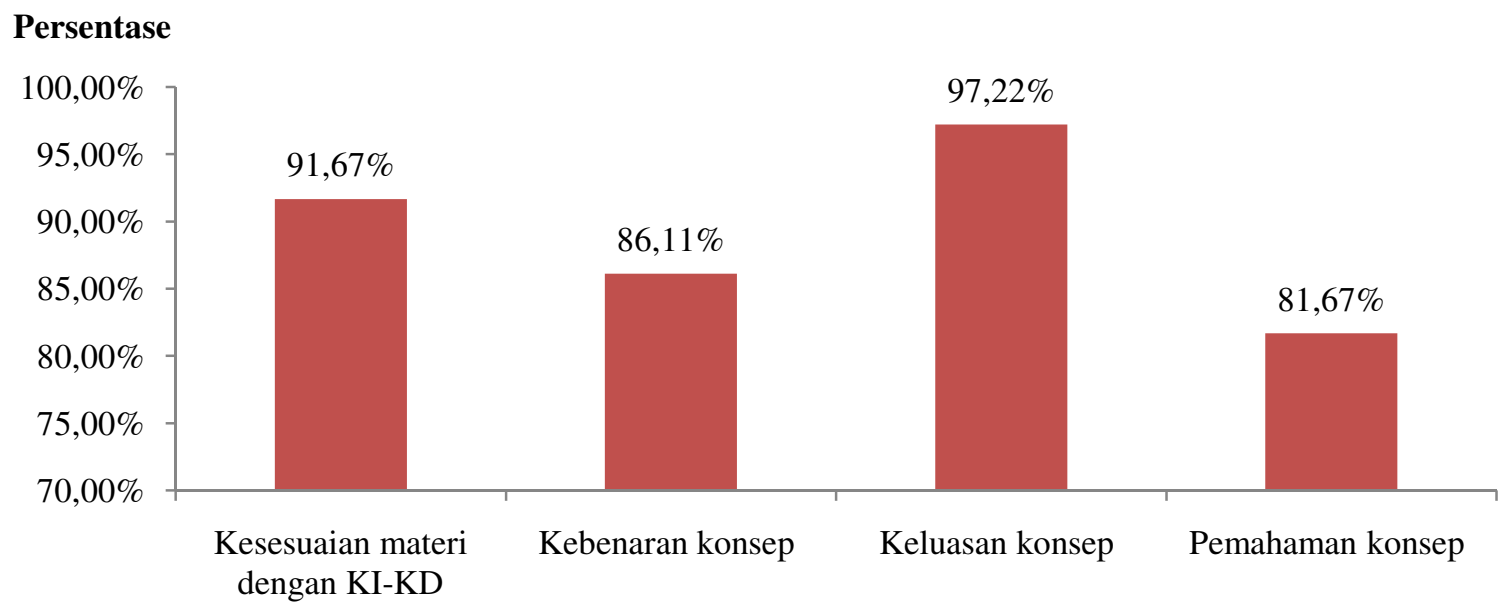

Gambar 1. Penilaian Kelayakan Isi LKS Berbasis Potensi Lokal Pada Mata Pelajaran Biologi SMA Kelas XII oleh Ahli Materi

Pada kelayakan penyajian, diperoleh bahwa sub komponen teknik penyajian memiliki persentase rata-rata $86.46 \%$, pendukung penyajian $97.92 \%$, penyajian pendekatan saintifik $86.90 \%$ dan penyajian potensi lokal 97.62\%. Untuk lebih jelasnya, hasil perolehan data grafik secara empiris dapat dilihat pada Gambar 1.2. berikut ini.

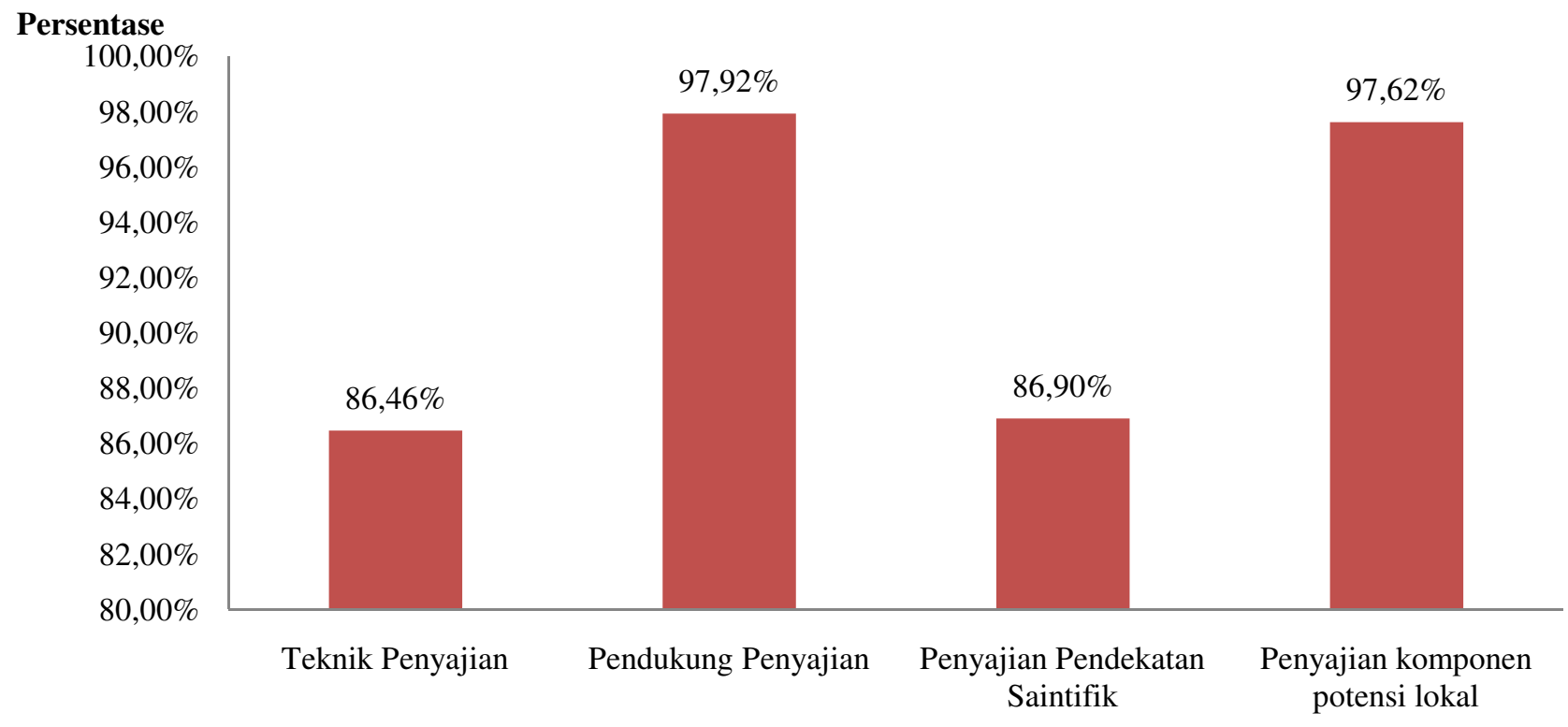

Gambar 2. Penilaian Kelayakan Penyajian LKS Berbasis Potensi Lokal Pada Mata Pelajaran Biologi SMA Kelas XII oleh Ahli Materi

Pada kelayakan aspek desain, penilaian aspek desain adalah 97\% dengan persentase rata-rata seluruh sub komponen kriteria "sangat baik". Komponen 
kelayakan ukuran LKS yang meliputi sub komponen format LKS memiliki persentase rata-rata $100 \%$. Komponen desain sampul yang terdiri dari sub komponen tata letak sampul LKS memiliki persentase rata-rata $95.83 \%$, tipografi desain sampul LKS 97.50\%, dan ilustrasi sampul LKS 93.75\%.
Komponen desain isi LKS yang meliputi tata letak memiliki persentase rata-rata $100 \%$, tipografi $91.67 \%$ dan ilustrasi/gambar isi LKS 95.83\%. Untuk lebih jelasnya, hasil perolehan data grafik secara empiris dapat dilihat pada Gambar 1.3 berikut ini.

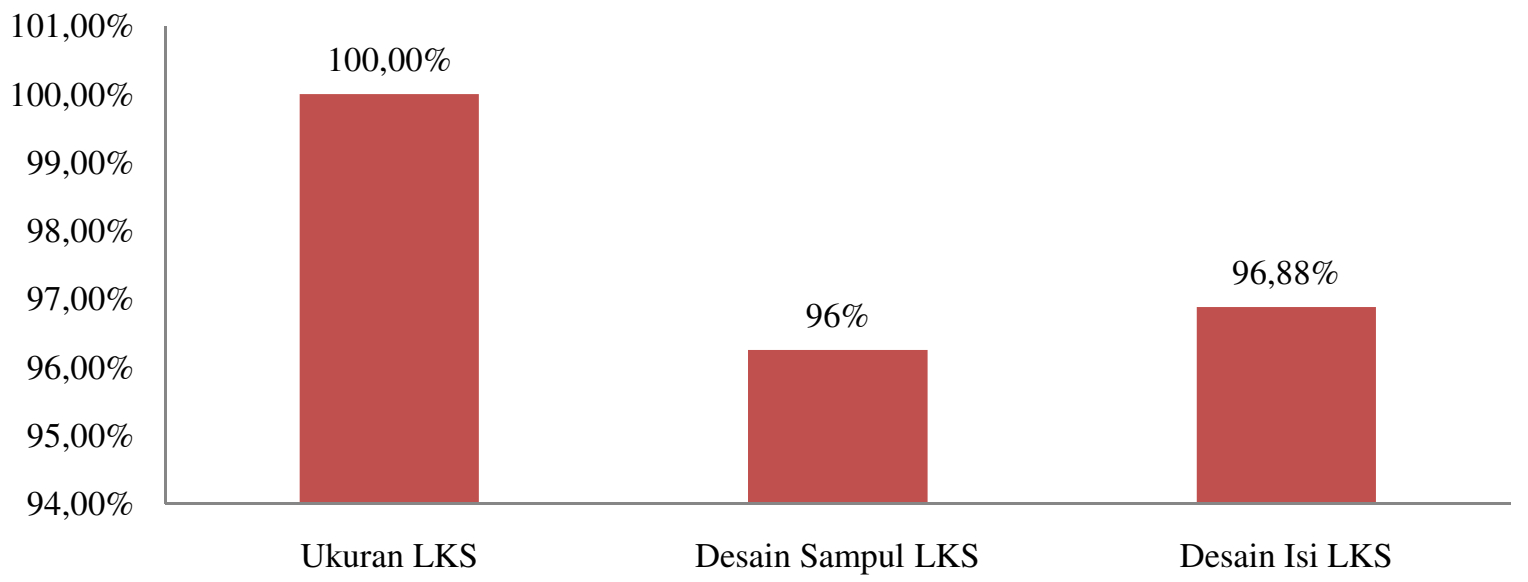

Gambar 3. Penilaian Kelayakan Ukuran, Desain Sampul dan Desain Isi LKS Berbasis Potensi Lokal Pada Mata Pelajaran Biologi SMA Kelas XII oleh Ahli Desain

Kelayakan LKS secara teoritis dinilai berdasarkan rata-rata dari aspek yang telah ditentukan yaitu kelayakan isi, kelayakan penyajian, kelayakan desain yang masingmasing aspeknya terdiri dari beberapa komponen. Aspek tersebut merupakan gambaran dari syarat LKS yang baik menurut Trianto (2010), yaitu syarat didaktik (isi) dan syarat konstruksi (kebahasaan), sedangkan syarat yang terakhir yaitu syarat teknik (penulisan, gambar dan penampilan).

Aspek kelayakan isi LKS biologi berbasis potensi lokal dinyatakan sangat layak. Semua sub komponen kelayakan isi yaitu kesesuaian materi dengan KI dan KD; kebenaran konsep; keluasan konsep; dan pemahaman konsep memiliki kriteria "sangat baik". Hal ini dikarenakan dalam penyusunan LKS mengacu pada tujuan pembelajaran serta uraian materi yang telah sesuai dengan kompetensi inti (KI) dan kompetensi dasar (KD), sebagaimana halnya persyaratan untuk penyusunan sumber belajar yang baik. Kariem (2013) menyatakan bahwa dalam menyusun sumber belajar perlu memperhatikan kurikulum.

LKS yang dikembangkan disusun berdasarkan syarat-syarat penyusunan LKS yang baik, selain itu LKS juga disusun dengan susunan yang sesuai menurut Depdiknas (2004) yang diawali dengan menganalisis kurikulum, menyusun peta kebutuhan LKS, menentukan judul LKS yang akan dikembangkan, dan kemudian mulai menulis LKS.

Hal ini dapat dilihat dari materi LKS yang memuat kebenaran fakta, konsep, prinsip dan prosedur, berdasarkan konsep dan teori yang berlaku dalam bidang ilmu biologi. Dengan demikian isi materi LKS dapat dipertanggungjawabkan secara ilmiah, benar dari segi keilmuan. Teori dan konsep materi serta aktivitas dalam LKS ini diperoleh dari beberapa buku teks dan buku ajar biologi yang telah ada. Berbagai informasi yang disajikan dalam LKS merupakan penelitian empiris yang diperoleh dari berbagai jurnal maupun berita-berita di situs website. Oleh karena itu, kelayakan isi materi dalam LKS yang 
dikembangkan ini dapat dijadikan materi pembelajaran di kelas XII SMA.

Kelayakan penyajian termasuk dalam kategori sangat layak. Penilaian kelayakan penyajian ini dibagi menjadi empat kriteria yaitu teknik penyajian, pendukung penyajian, penyajian pendekatan saintifik dan penyajian potensi lokal yang merupakan keunggulan dari LKS yang dikembangkan.

Teknik penyajian LKS termasuk ke dalam kriteria "sangat baik". Hal ini menunjukkan bahwa LKS sudah dituliskan dalam urutan yang sesuai dan saling berhubungan, serta dibantu dengan penggunaan bahasa yang baik.

Sistematika penulisan dalam LKS dinilai sangat baik karena LKS disajikan secara koherensi dan keruntutan alur berpikir, keterkaitan antar kalimat, paragraf dan konsep yang baik. Selain itu, materi LKS mudah dipahami siswa karena bahasa yang digunakan dalam LKS sesuai dengan tingkat perkembangan siswa serta kalimat yang digunakan dalam LKS jelas dan tidak menimbulkan makna ganda. Trianto (2010) menyatakan bahwa bahasa yang digunakan dalam menyusun kalimat pada LKS harus jelas, sederhana, dan sesuai dengan kemampuan siswa.

Tampilan LKS dianggap menarik bagi siswa karena desain LKS terlihat bagus dan tidak berlebihan, berisi hal-hal baru tentang potensi lokal Nias terkait dengan materi pembelajaran yang dapat menarik perhatian siswa. Penampilan sangat penting dalam LKS, karena siswa akan tertarik pada penampilan LKS sebelum membaca isinya (Trianto, 2010).

Pendukung penyajian termasuk ke dalam kriteria "sangat baik". Tingginya nilai tersebut karena LKS disajikan secara lengkap. Judul dalam LKS disesuaikan dengan materi. Hal ini sesuai dengan Prastowo (2012) yang menyatakan bahwa judul harus sesuai dengan KD atau materi pokok yang harus dicapai oleh siswa.

LKS juga memuat kolom identitas siswa dan kolom penilaian serta memiliki komponen utama seperti daftar isi, petunjuk penggunaan LKS, pengantar materi, info pendukung, lembar kerja/ kegiatan, daftar pustaka, dan identitas penyusun. LKS juga menyediakan ruangan yang cukup untuk memberi keleluasaan pada siswa untuk menuliskan jawaban atau menggambar pada LKS. Hal ini sesuai dengan syarat Prastowo (2011) dan Depdiknas (2004) bahwa struktur LKS secara umum minimal memuat judul, kompetensi dasar yang akan dicapai, waktu yang diperlukan untuk menyelesaikan, peralatan atau bahan yang diperlukan untuk menyelesaikan tugas, penjelasan singkat, langkah kerja, tugas yang harus dilakukan, dan laporan yang harus dikerjakan.

Penyajian pendekatan saintifik termasuk ke dalam kriteria "sangat baik" karena memuat langkah pendekatan saintifik melalui kegiatan mengamati, menanya, mengumpulkan informasi, mengasosiasi dan mengkomunikasikan konsep yang mereka temukan melalui aktivitas dalam LKS.

Penyajian potensi lokal dalam LKS termasuk ke dalam kriteria "sangat baik". Hal ini disebabkan karena potensi lokal yang disajikan dalam LKS berkaitan dengan materi biologi kelas XII dan membantu siswa memahami materi dengan baik. Sejalan dengan Sajidan (2013) yang menyatakan bahwa potensi lokal memberikan kesempatan bagi guru untuk memudahkan dalam mengaitkan pengetahuan baru yang akan disampaikan kepada siswa.

Penilaian pada aspek kelayakan desain mengacu pada beberapa indikator yaitu (1) kelayakan ukuran LKS yang meliputi format LKS; (2) kelayakan desain sampul LKS yang meliputi tata letak sampul LKS, tipografi desain sampul LKS, ilustrasi sampul LKS; dan (3) kelayakan desain isi LKS yang meliputi tata letak, tipografi dan ilustrasi/gambar isi LKS.

Kelayakan aspek desain LKS juga dinilai sangat baik. Nilai tersebut diperoleh karena tipe huruf dan ukuran yang digunakan dalam menyusun LKS mudah untuk dibaca, dipahami, jelas, serta ukuran yang sesuai. Depdiknas (2004) menyatakan bahwa dalam penyusunan bahan ajar cetak sangat penting memperhatikan stimulan/kemenarikan LKS dan kemudahan 
untuk dibaca. Hal ini didukung kuat dengan hasil validasi ahli desain pada komponen tipografi sampul dan tipografi isi yang masuk dalam kriteria "sangat baik".

Selain itu, kualitas gambar (foto) yang digunakan LKS gambar jelas, menarik, memperjelas penyampaian uraian, dan representatif untuk penyampaian konsep. Menurut Komalasari (2011) suatu gambar atau foto dapat memberikan gambaran nyata yang menunjukkan objek sesungguhnya, memberikan makna pembelajaran yang lebih hidup dan tepat dibanding dengan kata-kata sehingga merangsang kemampuan berpikir siswa. Dengan demikian, sumber belajar akan berpengaruh positif terhadap kegiatan pembelajaran, terutama pada peningkatan motivasi belajar siswa. Hal tersebut juga didukung dengan hasil validasi ahli desain terhadap ilustrasi/gambar isi LKS masuk ke dalam kriteria "sangat baik".

LKS dikemas dengan bagus, kertas sampul menggunakan kertas art paper 260 gram dan dilaminasi sehingga terlihat mengkilap dan tahan air, kertas LKS menggunakan kertas ukuran A4 80 gram sehingga tidak tembus jika digunakan bolak-balik. Hal tersebut juga didukung dengan hasil validasi ahli desain terhadap format LKS yang termasuk dalam kriteria "sangat baik".

\section{SIMPULAN}

Berdasarkan rumusan, tujuan, hasil dan pembahasan penelitian pengembangan LKS berbasis potensi lokal pada mata pelajaran biologi SMA kelas XII yang dikemukakan sebelumnya, maka dapat disimpulkan sebagai berikut:

1. Kelayakan isi dan kelayakan penyajian LKS biologi SMA kelas XII berbasis potensi lokal yang telah dikembangkan menurut ahli materi adalah sangat baik. Persentase skor rata-rata penilaian ahli materi terhadap kelayakan isi LKS adalah $88,10 \%$ dan aspek kelayakan penyajian LKS $91,35 \%$.

2. Kelayakan desain LKS biologi SMA kelas XII berbasis potensi lokal yang telah dikembangkan menurut ahli desain adalah sangat baik. Persentase skor rata-rata penilaian ahli desain terhadap kelayakan desain LKS adalah 97\%.

Berdasarkan hasil temuan yang telah diuraikan pada simpulan, berikut ini diajukan beberapa saran yaitu:

1. Mengingat bahwa hasil penelitian ini masih memungkinkan dipengaruhi oleh faktor-faktor yang belum mampu dikontrol, maka masih perlu dilakukan penelitian lebih lanjut pada sampel yang lebih banyak dan lebih luas.

2. Mengingat bahwa hasil penelitian ini hanya dilakukan sampai uji coba kelompok terbatas untuk menilai kelayakan LKS secara empiris, maka masih perlu dilakukan penelitian lebih lanjut untuk menguji efektifitas LKS yang dikembangkan, sehingga dapat diketahui apakah LKS yang dikembangkan berpengaruh nyata terhadap hasil pembelajaran dan meremediasi miskonsepsi sehingga dapat dilakukan tahap penyebaran produk (dissemination).

\section{DAFTAR PUSTAKA}

Ahmadi, I., Amri, S., dan Elisah, T. 2012. Mengembangkan Pendidikan Berbasis Keunggulan Lokal. Jakarta: Prestasi Pustaka.

Arsyad, A. 2012. Media Pembelajaran. Jakarta: PT Raja Grafindo Persada.

Asmani, Ma'mur, J. 2012, Pendidikan Berbasis Keunggulan Lokal.Yogyakarta: DIVA Press.

Depdiknas. 2004. Pedoman Penyusunan Lembar Kerja Siswa Dan Skenario Pembelajaran Sekolah Menengah Atas. Jakarta: Direktorat Jendral Pendidikan Dasar dan Menengah.

Hamalik, O. 2008. Proses Belajar Mengajar. Jakarta: PT Bumi Aksara.

Kariem, F., Elvyanti, S., Gunawan, Mulyana. Pengembangan Bahan Ajar TIK SMP Mengacu Pada Pembelajaran Berbasis Proyek. Invotec, 9 (2):117-128.

Kemdikbud. 2013. Kurikulum 2013, Sekolah Menengah Atas (SMA)/ Madrasah Aliyah (MA). Jakarta: Direktorat Jendral Pendidikan Dasar dan Menengah.

Komalasari, K. 2011. Pembelajaran Kontekstual Konsep dan Aplikasi. Bandung: PT Refika Aditama. 
Novana, T., Sajidan, Maridi. 2014. Pengembangan Modul Inkuiri Terbimbing Berbasis Potensi Lokal Pada Materi Tumbuhan Lumut (Bryophyta) dan Tumbuhan Paku (Pteridophyta). Jurnal Inkuiri, 2(2): 108-122.

Peraturan Menteri Pendidikan dan Kebudayaan Republik Indonesia nomor 81 A Lampiran IV. 2013. Tentang Implementasi Kurikulum Pedoman Umum Pembelajaran. Jakarta.

Prastowo, A. 2011. Panduan Kreatif Membuat Bahan Ajar Inovatif, Jogjakarta: Diva Press.

Sajidan, 2014. Pembelajaran Biologi dengan Pendekatan Saintifik pada Implementasi Kurikulum 2013, Makalah disajikan dalam Seminar Nasional XI Pendidikan Biologi FKIP UNS.

Sarah, S., Maryono. 2014. Keefektivan Pembelajaran Berbasis Potensi Lokal dalam Pembelajaran Fisika SMA dalam Meningkatkan Living Values Siswa. Jurnal

Pendidikan Sains Universitas Muhammadiyah Semarang, 2(1):36-42.

Soyibo, K. 1995. A Review of Some Sources of Students' Misconceptions in Biology. Singapore Journal of Education, (15):1-11.

Sugiyono. 2015. Metode Penelitian Kuantitatif, Kualitatif, dan $R \& D$. Bandung: Alfabeta.

Suratsih, Budiwati, Suhandoyo, Wibowo, Y. 2010. Pengembangan Modul Pembelajaran Biologi Berbasis Potensi Lokal dalam Kerangka Implementasi KTSP SMA di Yogyakarta. Laporan Hasil Penelitian. Penelitian Unggulan UNY (Multitahun). Universitas Negeri Yogyakarta.

Tekkaya C. 2002. Misconceptions as Barrier to Understanding Biology. Journal of Education, (23):259-266.

Trianto. 2010. Mendesain Model Pembelajaran Inoatif-Progresif. Jakarta: Kencana Prenada Media

Group. 